\title{
Histological evaluation of gastric biopsies for diagnosis and treatment in eosinophilic gastroenteritis
}

HUGH J FREEMAN, MD, FRCPC, FACP

HJ FREEMAN. Histological evaluation of gastric biopsies for diagnosis and treatment in eosinophilic gastroenteritis. Can J Gastroenterol 1993;7(4): 343-348. A 44-year-old man with abdominal pain had eosinophilic gastroenteritis with peripheral blood eosinophilia. Endoscopic biopsy specimens fixed in both Bouin's or formalin fixatives were compared and tissue eosinophil counts were used to assess the response to pharmacological therapy with the $\mathrm{H}_{1}$ class antihistamine, ketotifen. A favourable clinical response resulted in resolution of clinical symptoms and improved eosinophil counts in peripheral blood and gastric biopsies. Ketotifen is a useful and safe alternative to long term systemic corticosteroid therapy in the management of eosinophilic gastroenteritis, a condition possibly underdiagnosed in endoscopy units that depend solely on Bouin's solution for fixation of mucosal biopsies.

Key Words: Biopsy fixation methods, Bouin's solution, Eosinophilic gastroenteritis and gastritis, Eosinophils, Ketotifen, Mast cells

Examen histologique des biopsies gastriques pour le diagnostic et le traitement de la gastro-entérite à éosinophiles

RÉSUMÉ: Un homme de 44 ans souffrant de douleur abdominale présentait une gastro-entérite à éosinophiles avec éosinophilie sanguine périphérique. Des spécimens de biopsies endoscopiques fixés sur formaline ou solution de Bouin ont été comparés et des numérations d'éosinophiles ont été utilisées pour mesurer la réponse au traitement pharmacologique avec l'antihistaminique de classe H1 kétotifène. Une réponse clinique favorable a été observée au plan des symptômes et des numérations d'éosinophiles dans le sang périphérique et les biopsies

Department of Medicine (Gastroenterology), University Hospital and University of British Columbia, Vancouver, British Columbia

Correspondence and reprints: Dr Hugh Freeman, Head UBC Gastroenterology, ACU F-137, University Hospital (UBC Site), 2211 Wesbrook Mall, Vancouver, British Columbia V6T IW5. Telephone (604) 822-7216, Fax (604) 822-7897

Received for publication June 25, 1992. Accepted April 5, 1993
$\mathrm{E}$ OSINOPHILIC GASTROENTERITIS IS a rare syndrome characterized by recurrent gastrointestinal symptoms, especially episodic abdominal pain, histological evidence of eosinophilic infiltrates in the gastrointestinal tract, and no evident underlying systemic disorder or parasitic infection (1-3). In most but not all patients, peripheral blood eosinophilia is detected $(2-4)$. The most common sites of involvement are the distal stomach and the small intestine and, less commonly, the large intestine (3). Diagnosis in some patients may be difficult because the characteristic histological features may have a patchy mucosal distribution or eosinophilic infiltrates may be most prominent in the muscularis externa or subserosal region (3). Moreover, the histological observations in the present case emphasize that detection of eosinophils may be made more difficult in some patients if Bouin's solution is the sole fixative used for endoscopic gastrointestinal biopsy specimens.

The treatment of this condition and other 'allergic' disorders of the gastrointestinal tract has proven frustrating and very difficult. Elimination diets and food withdrawal programs have not 
gastriques. Le kétotifene est une solution utile et sécuritaire au traitement prolongé aux corticostéroïdes dans le traitement de la gastro-entérite à éosinophiles, une maladie possiblement sous-évaluée dans les laboratoires d'endoscopie qui dépendent uniquement de la solution de Bouin pour la fixation des biopsies des muqueuses.

been uniformly successful (2). Corticosteroids may provide symptomatic benefit in some patients, but in others, side effects may be significant and, if steroids are discontinued, clinical relapse is frequent (5). Less experience has accumulated with sodium cromoglycate, and its value - if any - still remains controversial $(4,6,7)$. In this report, a patient with eosinophilic gastroenteritis is described who has been treated for over one year with ketotifen, an $\mathrm{H}_{1}$ antihistamine known to 'stabilize' mast cells. While the precise mechanism for the beneficial clinical effects of this medication require elucidation, ketotifen appears to be a very useful alternative to systemic corticosteroid therapy $(8,9)$. Evaluation of therapy in this and related disorders may be difficult, however, because symptoms are frequently intermittent and, as illustrated by the present patient, assessment of treatment 'endpoints' requires close correlation among clinical, laboratory and histological parameters.

\section{CASE PRESENTATION}

A 44-year-old male was initially seen by his family physician for abdominal pain in 1988. Treatment courses of added dietary fibre, isopropamide-trifluoperazine, cisapride, trime- butine maleate and hyoscyamine sulphate for a diagnosis of a functional gastrointestinal disorder had no clinical benefit. Investigations at another teaching hospital revealed: hemoglobin, $149 \mathrm{~g} / \mathrm{L}$; white blood cell count, $5.8 \times 10^{9} / \mathrm{L}$ with $19 \%$ eosinophils; platelets, $204 \times 10^{9} / \mathrm{L}$; total serum protein, $65 \mathrm{~g} / \mathrm{L}$; and serum albumin, $42 \mathrm{~g} / \mathrm{L}$. Upper gastrointestinal endoscopy showed thickened mucosal folds in the distal gastric antrum. Eosinophilic infiltrates were reported in gastric and duodenal mucosal biopsies. Flexible sigmoido. scopy and biopsy, as well as barium studies of the small and large intestine, were normal. No ova or parasites were detected in multiple fecal specimens. In December 1989, prednisone treatment led to resolution of abdominal pain. With cessation of steroid therapy, however, his abdominal pain recurred. In February 1990, treatment with sodium cromoglycate for two months had no symptomatic effect; however, in May

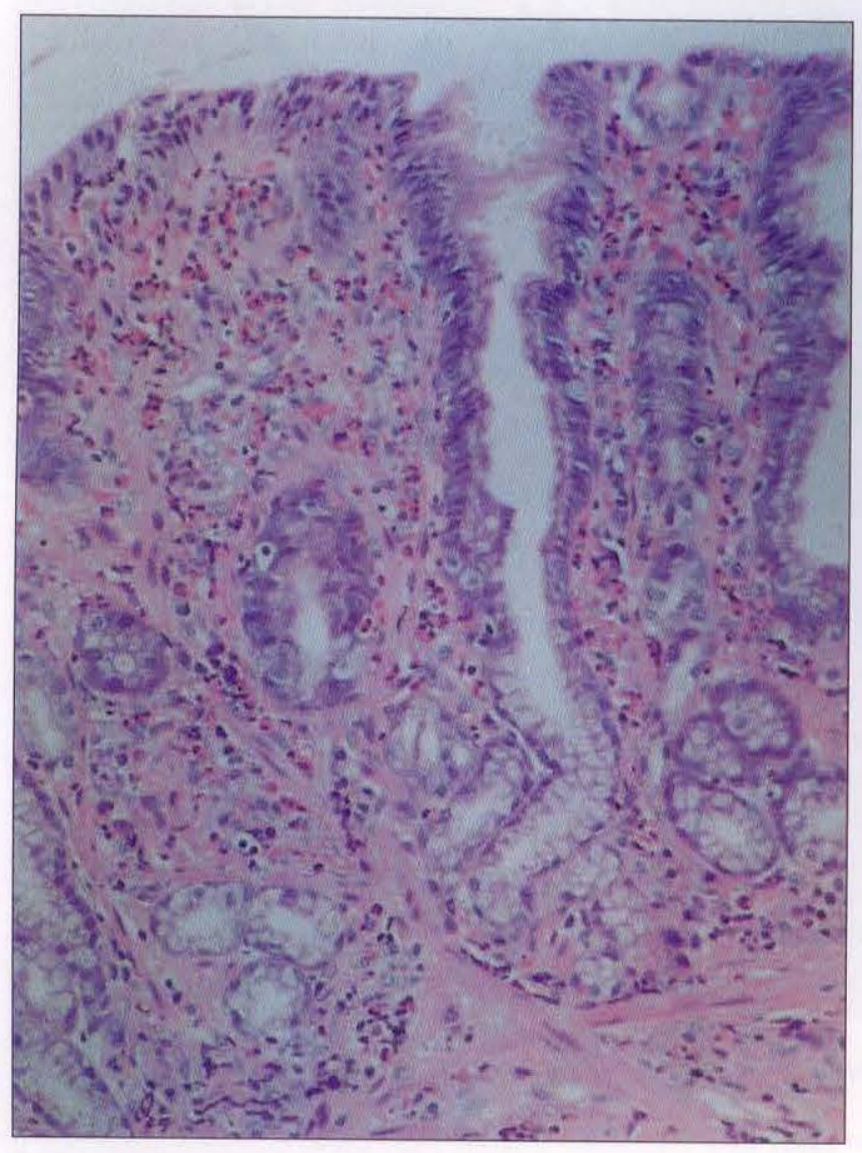

Figure 1) Pre-ketotifen formalin fixed gastric antral mucosal biopsy obtained in October 1990. Numerous eosinophils are present. Hematoxylin and eosin, $\times 200$

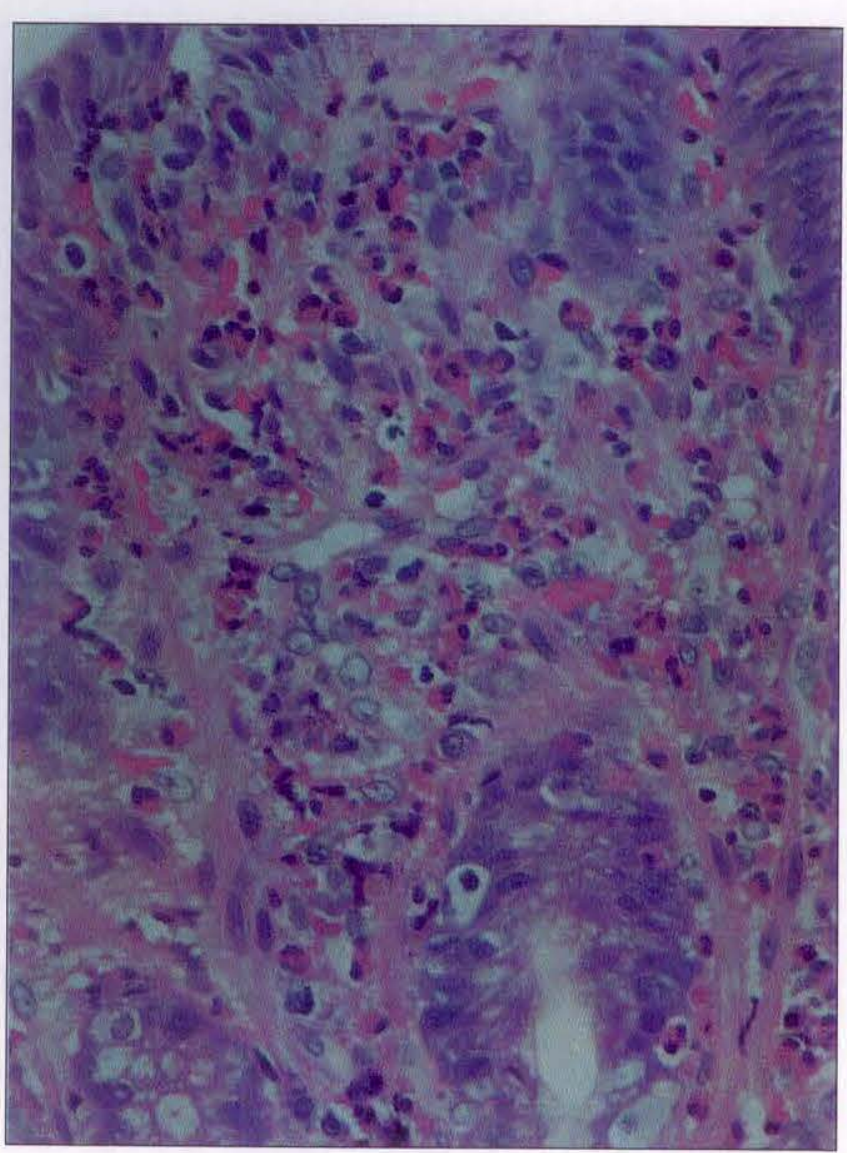

Figure 2) Photomicrograph showing a field from Figure 1 at higher power. Eosinophilic infiltrates are present in the lamina propria. Hematoxylin and eosin, $\mathrm{x} 400$ 


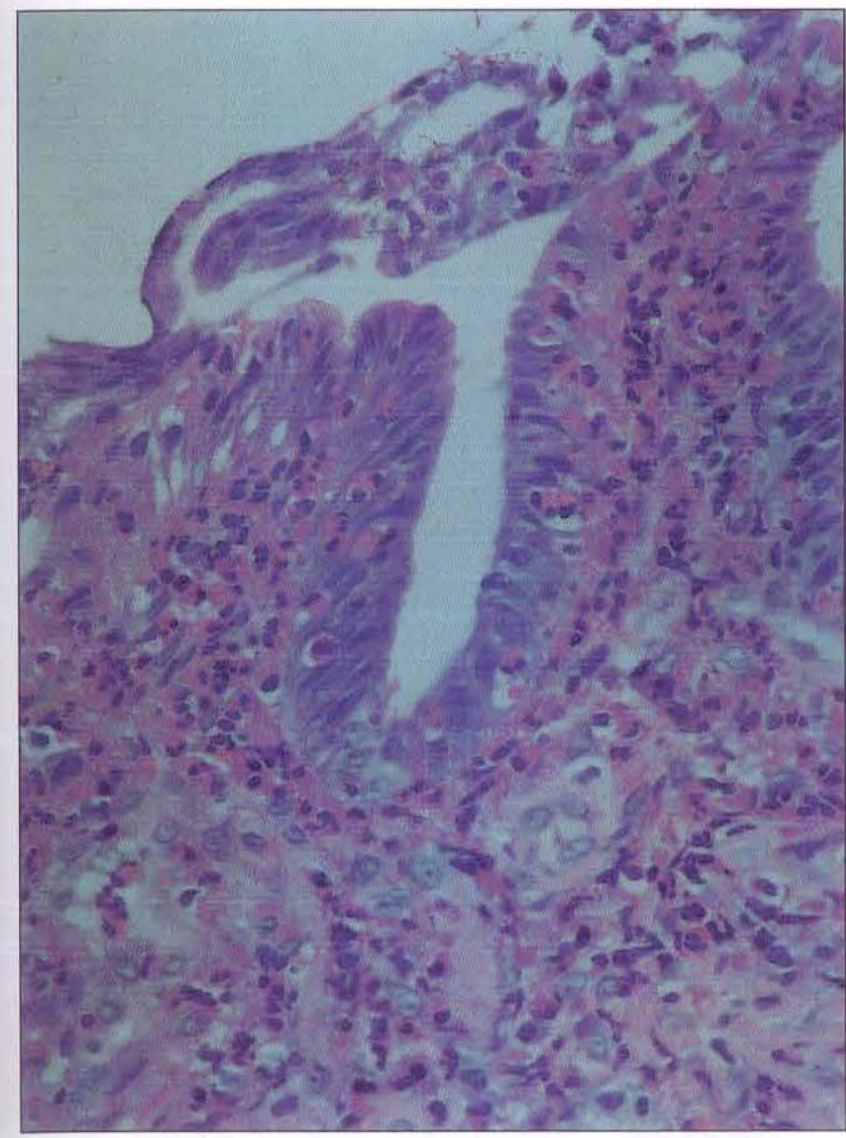

Figure 3) A separate photomicrographic field of formalin fixed gastric antral mucosa obtained in October 1990 showing sheets of eosinophils invading and migrating through the gastric surface epithelium into the gastric lumen. Hematoxylin and eosin, $\times 400$

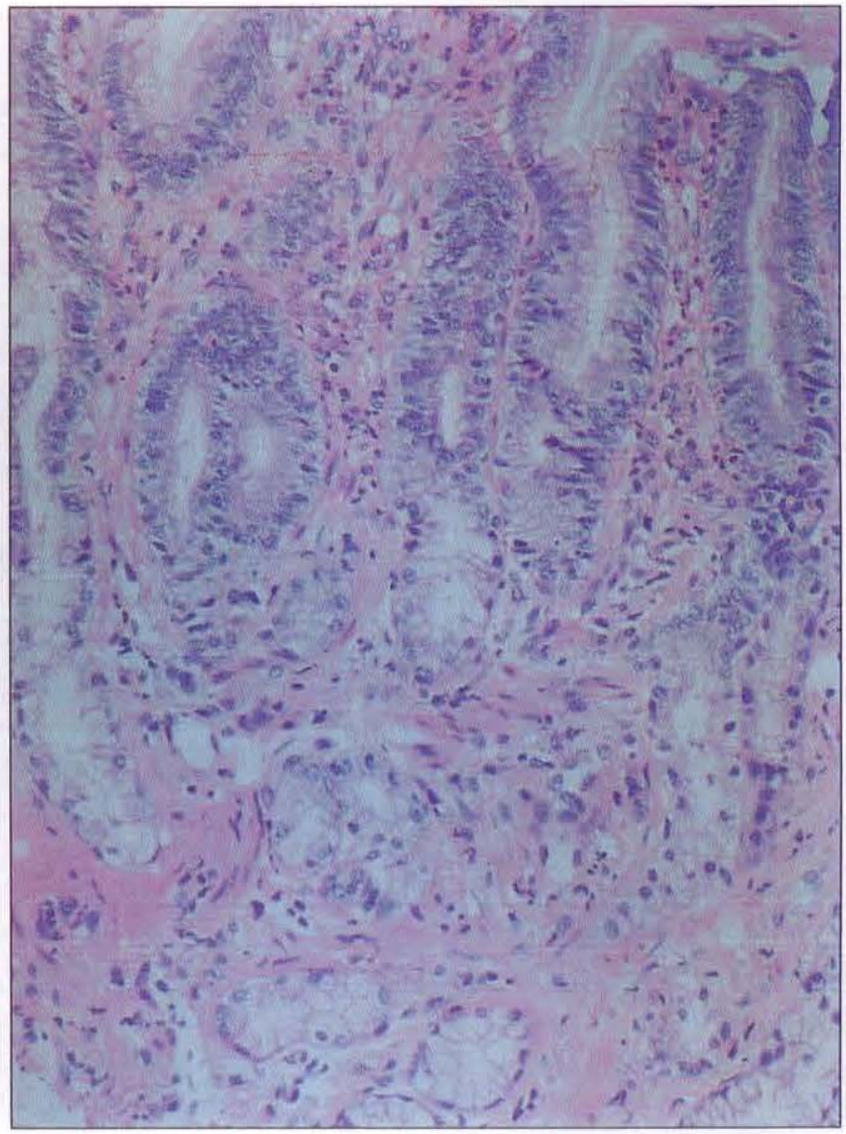

Figure 4) Pre-ketotifen Bouin's fixed gastric antral mucosal biopsy obtained in October 1990. Occasional eosinophils are present in the lamina propria and the gastric surface and neck epithelium (in contrast to Figure 1). Hematoxylin and eosin, $\times 200$
1990, his abdominal pain spontaneously resolved with no medication.

Because of recurrent abdominal pain, the patient was initially reviewed in September 1990. The pain was localized to the epigastrium (associated with nausea) and present each day, sometimes lasting for several hours with pain-free intervals for several hours. Weight loss was estimated to be $5 \mathrm{~kg}$. He had no fever, history of atopy or drug hypersensitivity. From April 1990, there was no use of medications, vitamins, nutritional supplements or food additives, specifically L-tryptophan (10). Physical examination was normal and his weight was $75 \mathrm{~kg}$. Laboratory studies included: hemoglobin, $149 \mathrm{~g} / \mathrm{L}$ (normal, 140 to 180 ); white blood cell count, $7.3 \times 10^{9} / \mathrm{L}$ (normal, 4.0 to 11.0 ); and platelet count, $237 \times 10^{9} / \mathrm{L}$ (normal, 140 to 350 ). The white blood cell differential, however, was abnormal with: polymorphonuclear leukocytes,
2.336 $\times 10^{9} / \mathrm{L}$ (normal, 2.0 to 8.0 ); band cells, $0.073 \times 10^{9} / \mathrm{L}$ (normal range, 0 to $0.7)$, lymphocytes, $2.190 \times 10^{9} / \mathrm{L}$ (normal, 1.0 to 4.0 ), monocytes, $0.584 \times 10^{9} / \mathrm{L}$ (normal, 0.1 to 0.8 ) and eosinophils, $2.117 \times 10^{9} / \mathrm{L}$ (normal, 0 to 0.45). Liver chemistry tests including bilirubin, alkaline phosphatase, transaminases, prothrombin time and albumin were normal. Multiple fecal specimens for bacterial pathogens, ova and parasites (x6) were negative. Upper gastrointestinal endoscopy in October 1990 showed gastric and duodenal mucosal hyperemia with prominent nodular gastric folds, particularly in the distal gastric antrum. Two biopsies were obtained from the duodenum, gastric antrum and gastric body; one biopsy from each site was fixed in formalin and Bouin's solution. Dense mucosal eosinophilic infiltrates were most evident in formalin fixed gastric biopsy specimens (Figures 1-4) and were typical of eosinophilic gastritis (mean number of eosinophils in Bouin's fixed gastric antral mucosa, 10.2 per high power field compared with formalin fixed gastric antral mucosa, 132.6; $\mathrm{n}$ = five randomly chosen microscopic fields). Scattered, rare eosinophils were present in biopsies from duodenum in either fixative. Duodenal smears of aspirated juice were negative for parasite larvae, in particular, Strongyloides stercoralis. Prednisone treatment, $20 \mathrm{mg}$ daily, led to resolution of his abdominal pain within two weeks and his weight increased by $5 \mathrm{~kg}$ to $80 \mathrm{~kg}$. His hemogram, specifically his eosinophilia, improved but did not completely normalize (white blood cell count, $7.9 \times 10^{9} / \mathrm{L}$ and absolute eosinophil count, $\left.0.751 \times 10^{9} / \mathrm{L}\right)$. Prednisone was tapered and discontinued in January 1991. However, malaise and abdominal pain rapidly recurred and his absolute eosinophil count increased to $3.042 \times 10^{9} / \mathrm{L}$. Upper gastrointestinal 
TABLE 1

Peripheral blood and gastric biopsy eosinophil counts*

\begin{tabular}{lcccc}
\hline Parameter & October 1990 & March 1991 & June 1991 & May 1992 \\
\hline Abdominal pain & Present & Present & Absent & Absent \\
Weight $(\mathrm{kg})$ & 75 & 73 & 77 & 80 \\
Eosinophils $^{\dagger}$ & 2.117 & 3.185 & 1.239 & 1.863 \\
Gastric eosinophils $^{\dagger}$ & 132.6 & 109.2 & 37.8 & Not done \\
\hline
\end{tabular}

"Eosinophil counts were done in October 1990 and March 1991 prior to ketotifen therapy, and in June 1991 and May 1992 on treatment with ketotifen: ' Absolute eosinophil counts in peripheral blood as cells $\times 10^{9} / \mathrm{L}:{ }^{\dagger}$ Gastric eosinophil counts done on independently coded, randomized sections of gastric antral mucosa as mean number of eosinophils/high power microscopic field ( $n=$ five fields)

endoscopy showed diffuse gastric mucosal erythema with nodular folds along with an $8 \mathrm{~mm}$ gastric antral ulcer. Gastric biopsies revealed benign changes with eosinophils. Dieterle stains for Helicobacter pylori were negative (11). Treatment with omeprazole, $20 \mathrm{mg}$ daily, resulted in resolution of pain within two weeks. The patient's eosinophil count, however, remained abnormal at $2.366 \times 10^{9} / \mathrm{L}$.

In March 1991, after an eight-week course of omeprazole, a further upper gastrointestinal endoscopy revealed swollen and exythematous gastric mu- cosa but the patient's gastric ulcer was healed. Gastric body and antral biopsies showed eosinophilic infiltrates, and mucosal eosinophil counts are recorded in Table 1. An upper gastrointestinal barium study confirmed the appearances of prominent gastric antral mucosal folds (Figure 5) but the patient's small intestine was normal. Although his total white blood cell count was normal, an absolute eosinophil count increased further to $3.185 \times 10^{9} / \mathrm{L}$. Over the next few days, pain recurred. $\mathrm{Ke}$ totifen $2 \mathrm{mg}$ daily resulted in resolution of pain in two weeks, and eosinophil count improved to $1.702 \times 10^{9} / \mathrm{L}$. Al- though symptoms did not recur, his absolute eosinophil count was repeated after two additional weeks on ketotifen. No further improvement in his eosinophilia $\left(1.760 \times 10^{9} / \mathrm{L}\right)$ was seen and it was elected to increase the dose of ketotifen to $4 \mathrm{mg}$ daily. During the next eight weeks the patient remained well and his weight increased to $77 \mathrm{~kg}$. In June 1991, his absolute eosinophil count fell to $1.239 \times 10^{9} / \mathrm{L}$. Upper gastrointestinal endoscopy revealed prominent, erythematous gastric body and gastric antral folds. Biopsies from the gastric body and gastric antrum revealed sparse, but persistent, eosinophilic mucosal infiltrates (Figure 6) as recorded in Table 1. The patient remained well to May 1992 during a oneyear period on continuous ketotifen therapy. Abdominal pain has not recurred and his weight has increased to $80 \mathrm{~kg}$. Laboratory blood tests were normal in May 1992 except for an absolute eosinophil count of $1.863 \times 10^{9} / \mathrm{L}$. The patient refused further endoscopic and histological studies. No apparent side effects of ketotifen therapy were reported.

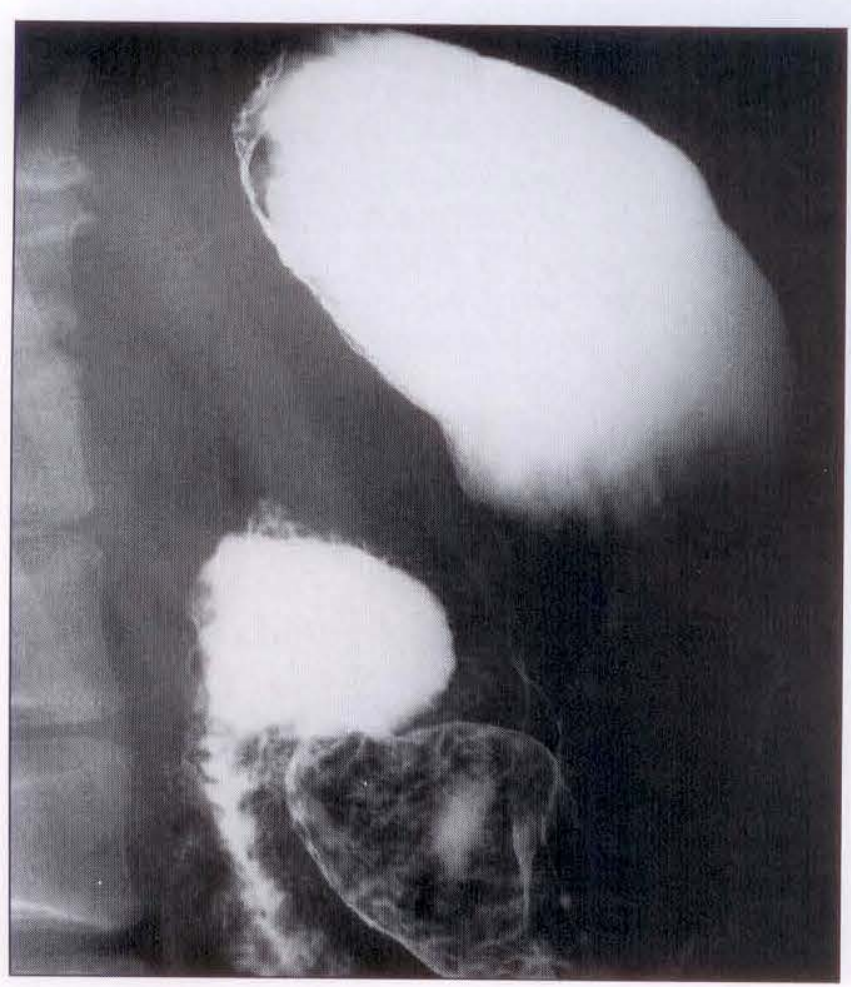

Figure 5) Barium radiograph of the stomach. Prominent gastric antral mucosal folds are present. The remainder of the stomach and small intestine are normal

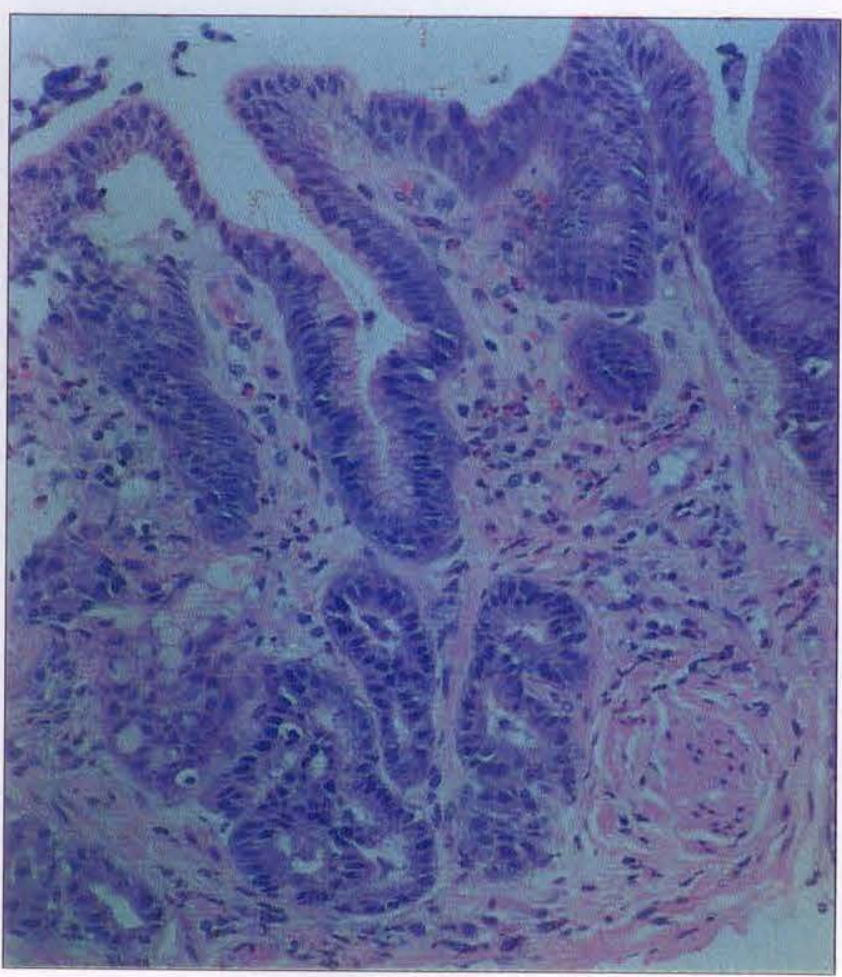

Figure 6) Post ketotifen formalin fixed gastric antral mucosal biopsy obtained in June 1991. Eosinophils are still present and readily identified, but are significantly reduced in number. Hematoxylin and eosin, $\times 200$ 


\section{DISCUSSION}

The patient described in the present report fulfilled previously proposed criteria for diagnosis of eosinophilic gastroenteritis (1-3). Although eosinophils may be a part of the inflammatory response in a wide variety of gastrointestinal disease processes, this syndrome is relatively rare and characterized by several features: gastrointestinal symptoms, particularly abdominal pain and/or diarrhea; eosinophilic infiltrates, most frequently in the distal stomach and/or small intestine, often with peripheral blood eosinophilia (4); and a requirement for exclusion of other obvious causes, including parasites, other systemic diseases (3) as well as drug- and chemically-induced diseases that can mimic idiopathic eosinophilic gastroenteritis (including the eosinophilia-myalgia syndrome associated with ingestion of L-tryptophan) (10). Although the patient's diagnosis was well established, our initial studies emphasized difficulties that could be encountered if biopsy fixation is not optimal for detection of eosinophilic infiltrates. It has been stated elsewhere that Bouin's fixative has the disadvantage of leaching eosinophil granules (3). The histological studies illustrated here indicate that even dense mucosal eosinophilic infiltrates were poorly defined in Bouin's fixed endoscopic biopsies compared with formalin fixed material from adjacent biopsy sites, and if the clinician suspects that eosinophilic gastritis or gastroenteritis is present, Bouin's solution represents an inferior fixative and should not be employed. Formalin probably still remains the most commonly used fixative in most hospitals but Bouin's solution is also very popular (including in our own

\section{REFERENCES}

1. Klein NC, Hargrove RL, Sleisenger MH, Jeffries GH. Eosinophilic gastroenteritis. Medicine 1970;49:299-319.

2. Cello JP. Eosinophilic gastroenteritis a complex disease entity. Am J Med 1979;67:1097-104.

3. Lewin KJ, Riddell RH, Weinstein WM. Gastrointestinal Pathology and its Clinical Implications. Volume II. Tokyo: Igaku-Shoin, 1989:782-4. endoscopy unit) because it rapidly fixes small specimens and produces less shrinkage artefact compared with formalin; thus, it is conceivable, especially in those centres that use Bouin's fixation for endoscopic material, that eosinophilic gastroenteritis occurs more commonly than currently is recognized.

Although eosinophilic infiltrative disorders represent a broad disease spectrum (12), the most common sites of involvement in eosinophilic gastroenteritis are the distal stomach and the small intestine (4). The precise role of endoscopic biopsy in establishing this diagnosis, however, has only been examined to a limited extent. The potential utility of endoscopic gastric biopsies was previously emphasized, even in the absence of gastric outlet obstruction or other significant macroscopic changes (13). In addition, diagnosis may be difficult because eosinophilic infiltrates can have a patchy mucosal distribution (14) or be most prominent in the muscularis externa or subserosa, not accessible to routine endoscopic biopsy forceps (12). Finally, the literature suggests that even definitions of 'diagnostic' gastrointestinal infiltrates are variable, and range from 10 to 50 eosinophils per high power field, either diffusely or multifocally within the lamina propria $(4,15,16)$. In the esophagus, even fewer eosinophils are 'acceptable' with the suggestion that concurrent changes in the stomach or small intestine are necessary for diagnosis (16). Although the patient reported here satisfied all of these previously published histological criteria, more precise quantitative pathological descriptions of eosinophilic infiltrates are needed.

The pathogenesis of eosinophilic gastroenteritis is poorly understood. A

4. Talley NJ, Shorter RG, Phillips SF, Zinsmeister AR. Eosinophilic gastroenteritis: A clinicopathological study of patients with disease of the mucosa, muscle layer, and subserosal tissues. Gut 1990;31:54-8.

5. Robert F, Omura E, Durant JR. Mucosal eosinophilic gastroenteritis with systemic involvement. Am J Med 1977;62:139-43.

6. Moots RJ, Prouse P, Gumpel JM. Near fatal eosinophilic gastroenteritis responding to oral number of potentially cytotoxic proteins have been detected in eosinophil granules, including major basic protein, eosinophil-derived neurotoxin, eosinophil cationic protein and eosinophilic peroxidase (17). Direct cellular damage to gastric and/or intestinal mucosa might result if degranulation and release of these substances occurred. Eosinophils also produce inflammatory mediators, ie, leukotriene $\mathrm{C}_{4}$ and platelet activating factor, that could damage the mucosa (18). Alternatively, eosinophils might indirectly activate mast cells to release histamine and other potentially harmful inflammatory mediators $(19,20)$. Recent reports have suggested that ketotifen, an $\mathrm{H}_{1}$ class antihistamine, might be used in treatment of eosinophilic gastroenteritis $(8,9)$. Although ketotifen has been used in a number of allergic disorders, including extrinsic asthma (21), its precise mechanism of action has not been determined. Ketotifen stabilizes mast cell membranes and possibly impairs the chemotactic migration of eosinophils into tissues $(9,21)$. In addition, histamine release and leukotriene production may be impaired (9). Clinical improvement and 'clearing' of eosinophilic infiltrates from gastric biopsies were previously reported, suggesting that continuous ketotifen treatment might be a safer alterative to more traditional systemic corticosteroid therapy (9). The observations in our patient, based on quantitative morphological assessment of endoscopic biopsies, would add further support for ketotifen therapy in this disorder, particularly as a steroid sparing agent. Additional studies may elucidate the mechanism of action of ketotifen and its possible therapeutic role in clinical disorders.

sodium chromoglycate. Gut 1988;29:1282-5.

7. Heatley RV, Harris A, Atkinson M. Treatment of a patent with clinical features of both eosinophilic gastroenteritis and polyarteritis nodosa with oral sodium cromoglycate. Dig Dis Sci 1980;25:470-2.

8. Esteban-Carretero J, Ruiz-Cabello M, Lacarcel-Femandez E, AneirosCachaza J, Rodrigo-Moreno M. Gastroentritis eosinofila resistente a tratamiento con corticoides y buena 
respuesta al cromoglicato disodico y ketotifeno. Gastroenterol Hepatol 1986;9:178-81.

9. Melamed I, Feanny SJ, Sherman PM, Roifman CM. Benefit of ketotifen in patients with eosinophilic gastroenteritis. Am J Med 1991;90:310-4.

10. De Schryver-Kecskemeti K, Bennett KW, Cooper GS, Yang P.

Gastrointestinal involvement in L-tryptophan (L-Trp) associated eosinophilia-myalgia syndrome (EMS), Dig Dis Sci 1992;37:697-701.

11. McGovem TW, Talley NJ, Kephart GM, Carpenter HA, Gleich GJ. Eosinophil infiltration and degranulation in Helicobacter pylori-associated chronic gastritis. Dig Dis Sci 1991;36:435-40.

12. Suen KC, Burton JD. The spectrum of eosinophilic infiltration of the gastrointestinal tract and its relationship to other disorders of angiitis and granulomatosis. Hum Pathol 1979;10:31-43.

13. Katz A, Goldman H, Grand RJ. Gastric mucosal biopsy in eosinophilic (allergic) gastroenteritis.

Gastroenterology 1977;73:705-9.

14. Leinbach GE, Rubin CE. Eosinophilic gastroenteritis: A simple reaction to food allergens? Gastroenterology 1970;59:874-89.

15. Tedesco FJ, Huckaby CB, Hamby-Allen M, Ewing GC. Eosinophilic ileocolitis: Expanding spectrum of eosinophilic gastroenteritis. Dig Dis Sci 1981;26:943-8.

16. Case Records of the Massachusetts General Hospital. Case 20. N Engl J Med 1992;326:1342-9.
17. Gleich GJ, Ottesen EA, Leiferman KM, Ackerman SJ. Eosinophils and human disease. Int Arch Allergy Appl Immunol 1989;88:59-62.

18. Gleich GJ, Adolphson CR. The eosinophil leukocyte: Structure and function. Adv Immunol 1986;39:177-253.

19. Befus AD, Dyck N, Goodacre R, Bienenstock J. Mast cells from human intestinal lamina propria. Isolation, histochemical subtypes, and functional characterization. J Immunol 1987;138:2604-10.

20. Lee TDG, Swieter M, Befus D. Mast cells, eosinophils and gastrointestinal hypersensitivity. Immunol Allergy Clin 1988;8:469-83.

21. MacDonald GF. An overview of ketotifen. Chest 1982;82:30S-2. 


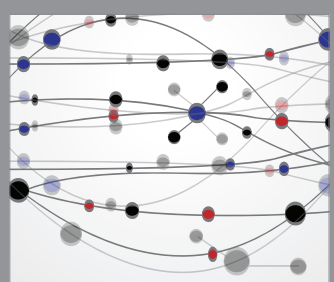

The Scientific World Journal
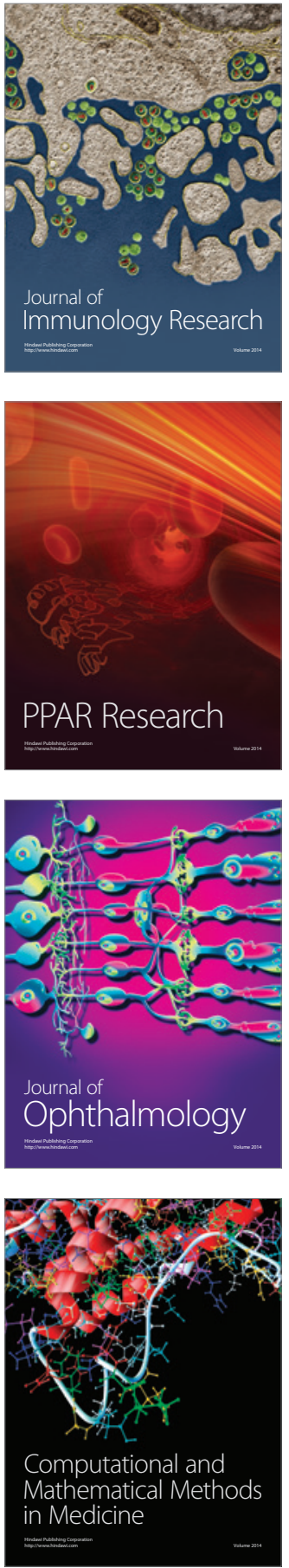

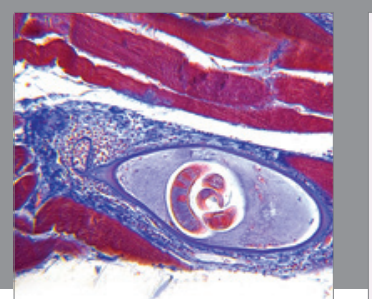

Gastroenterology Research and Practice

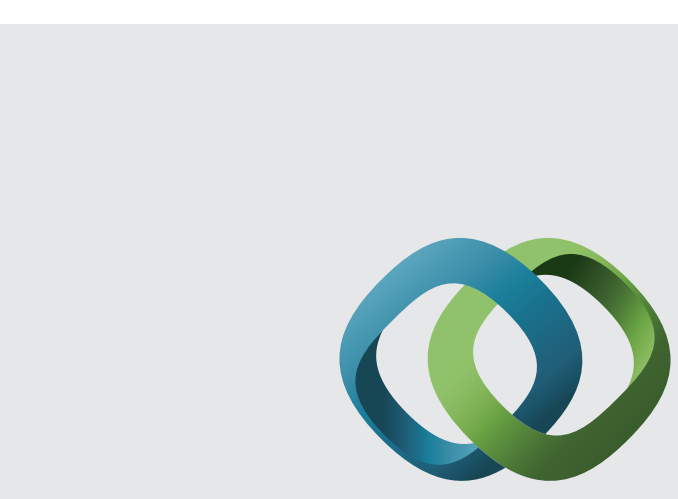

\section{Hindawi}

Submit your manuscripts at

http://www.hindawi.com
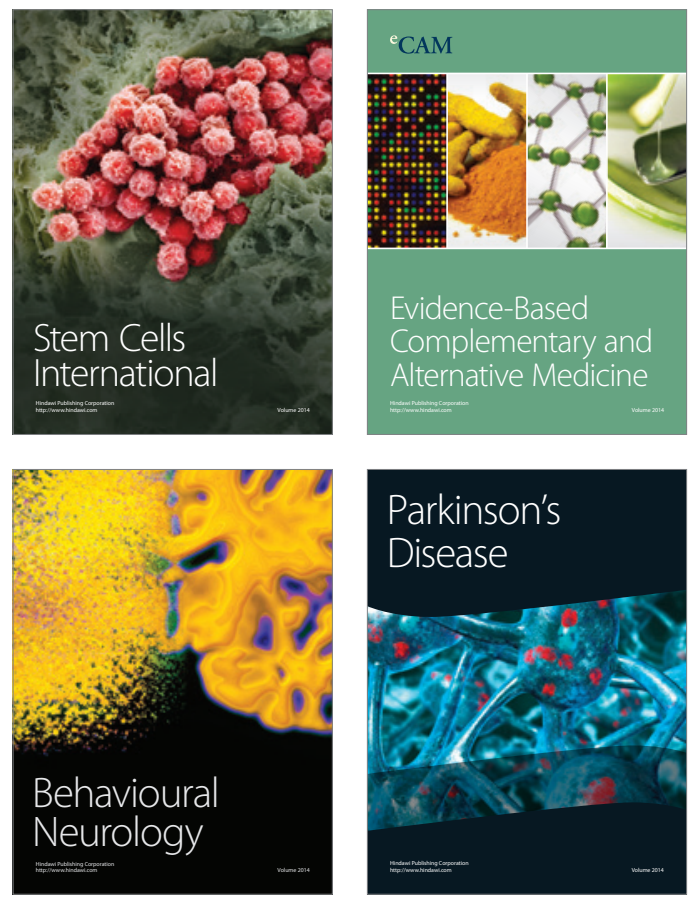
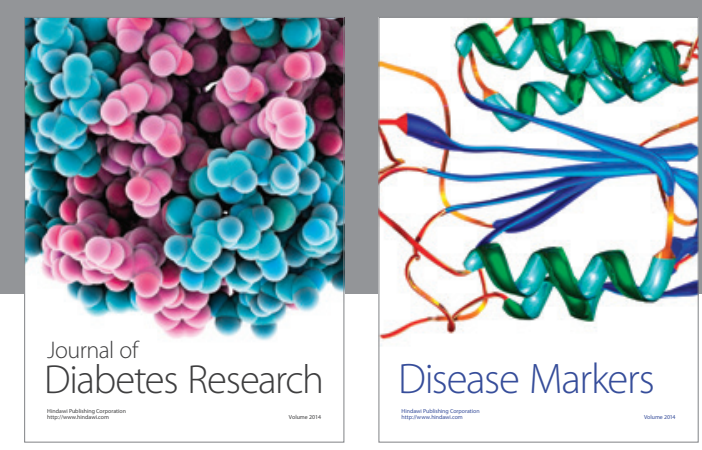

Disease Markers
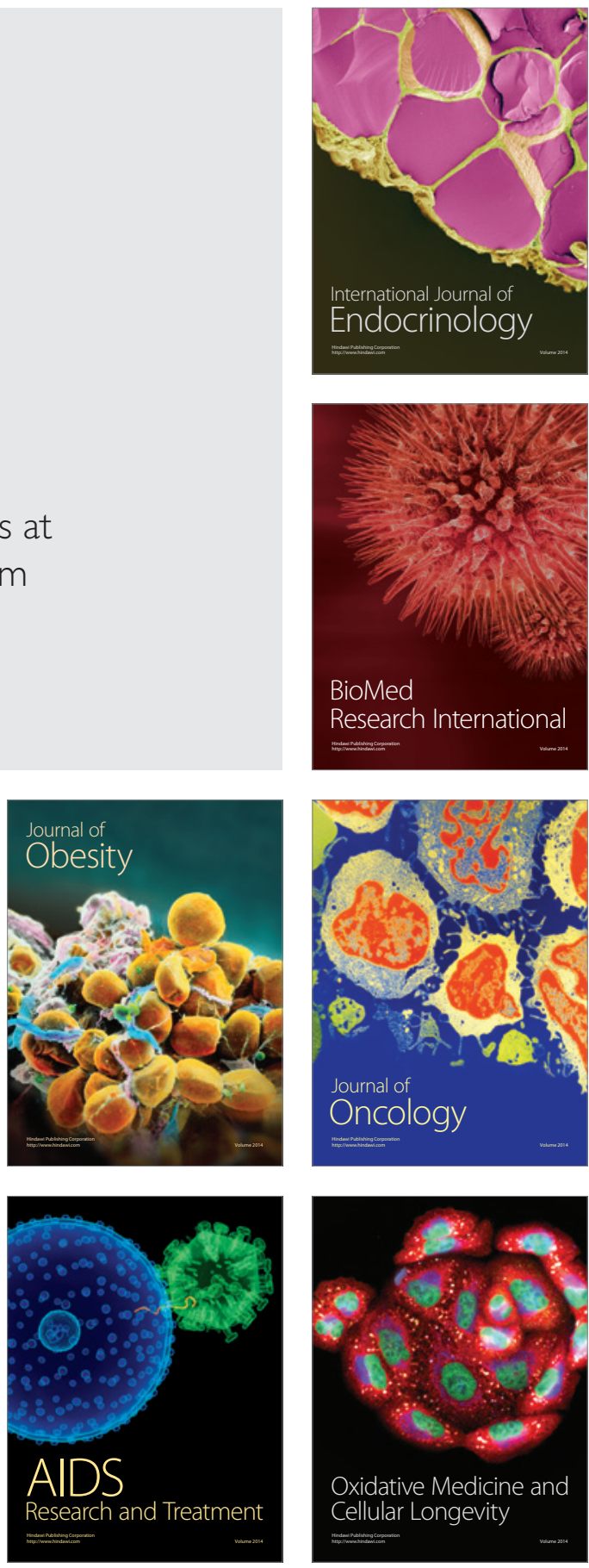